\title{
OBSERVATIONS ON THE FORMATION OF PROTECTION WOOD ${ }^{1}$
}

\section{BY ERIK JORGENSEN 2}

Mature individuals of a number of coniferous and deciduous tree species (pines, oaks, elms, etc.) have in the central part of their stems a coloured heartwood core. This heartwood is impregnated with phenolic substances, and in deciduous tree species contains tyloses formations.

In other tree species (spruces, beeches, maples, etc.), a visibly differentiated heartwood does not normally occur.

This difference between wood of different tree species attracted early the attention of botanists, and led to attempts to classify trees accordingly into "heartwood" and "sapwood" species. Such a classification seemed no doubt justified at the time, because the "heartwood" species, taken as a whole, are more resistant to fungus decay and deterioration than are the "sapwood" species. However, as we shall see, this grouping is an artifact, and can no longer be upheld.

Botanical literature contains abundant records of the occurrence of "Pathological" (or "false") heartwood in tree species belonging to both of the above groups. A close examination of these records shows that whatever term has been applied, they deal with parts of the sapwood which have been changed in such a way that they have the following characteristics which are identical with the heartwood characteristics:

1. The wood is coloured.

2. The wood contains phenolic substances not found in live sapwood and identical to those found in heartwood of the same tree species.

3. The wood is more resistant to fungus decay than unchanged sapwood.

4. The wood contains tyloses formation in deciduous trees identical to those found in the heartwood of the same species where present.

The reasoning behind the application of terms other than strictly "heartwood" to these occurrences is no doubt to be found in the facts listed below:

(a) All of these occurrences can be found in species that are definitely "sapwood" as well as in "heartwood" species, but has particularly attracted attention when found in the former.

(b) Pathological heartwood occurs in connection with mechanical wounds or fungus infections and rarely in the central part of the stem.

(c) Red wood or false heartwood form an irregular stained pattern in the central stem, superficially not resembling heartwood which in most species has an even circumference.

Consideration of the points 1 to 4 and (a) to (c) shows that pathological heartwood, red wood, and false heartwood differ from heartwood only in the location within the stem and in occurrence in tree species.

\footnotetext{
${ }^{2}$ Paper presented at the annual meeting of The Canadian Phytopathological Society, June 21st, 1962 in Ottawa.

${ }^{2}$ Assistant Professor, Faculty of Forestry, University of Toronto, Toronto, Ont.
} 
Surprisingly little experimental work has been undertaken to classify the problems concerning the physiology and chemistry of heartwood formation. Further, the isolation and identification of chemical extractives from heartwood was most difficult until the recent introduction of chromatography. For these reasons, various theories on heartwood formation have been put forward, and of these the following three appear to have the most supporters.

1. Heartwood is formed in dead sapwood by autoxidation of the cell content following the penetration of air.

2. Heartwood is formed as a result of fungus activity in the pith and central stem.

3. Heartwood formation is directed by the cambium in which the chemical heartwood extractives are formed, later to be translocated to the central part of the stem.

These three theories have in common that they are based on observations of heartwood which has been formed, and are not supported by experimental evidence.

The present author in a recent publication (Jorgensen 1961) reported on the formation of the heartwood extractives, pinosylvin and pinosylvin monomethyl ether in the sapwood of red pine (Pinus resinosa Ait.).

Experimental evidence demonstrated that these compounds were formed by living cells in the sapwood under the influence of desiccation and/or aeration. Furthermore, considering the location of the pinosylvin formation and the known toxicity of these extractives, it was concluded that they are formed as part of a natural defensive reaction, which can be triggered in the sapwood by wounding and by fungus penetration.

Findings and conclusions similar in principle were made by Zycha (1948) in a study of red wood (or false heartwood) formation in European beech (Fagus silvatica L). Zycha found that red wood in beech was similar in all respects to heartwood in other tree species, and he demonstrated tyloses formation and browning resulting from artificial aeration of live sapwood samples.

This work has just recently come to the attention of the author, but must be considered of prime importance in the understanding of heartwood formation as a physiological process.

From consideration of the evidence given by Zycha (1948) and Jorgensen (1961), it becomes evident that none of the above listed theories about heartwood formation are correct. Heartwood is, according to the available information, formed in live sapwood by a change in the metabolism of dying cells exposed to aeration and/or desiccation (processes which at present cannot be separated in live tissues). The aeration in heartwood formation occurs, no doubt, through the pith (Zycha, 1948 and Paclt, 1953) which in older trees invariably is connected with dead branch stubs, and therefore is in direct contact with the air outside the tree. Zycha (1948) indicated that changes in moisture content in the stem may lead to aeration due to changes in air pressure, and Paclt (1953) suggested that air moves from dead roots to dead branch stubs through the pith during winter when the soil temperature is higher than the air temperature.

The biological importance of heartwood formation may be seen in the provision for the impregnation of dead cells in the central stem and the 
protection afforded live cells against air penetration (tyloses, gum, and resin formation). All the evidence points to the fact that pathological heartwood and red wood (or false heartwood) provide a similar function. It is therefore suggested that all of these occurrences should be covered by one term"protection wood," and that the terms "heartwood" and "pathological heartwood" can continue to be used-"heartwood" with reference to the formation of protection wood in the central stem, and "pathological heartwood" with reference to the formation of protection wood in direct response to mechanical injury or fungus penetration.

\section{LITERATURE}

JORGENSEN, ERIK. 1961. The Formation of Pinosylvin and its Monomethyl Ether in the Sapwood of Pinus resinosa Ait. Can. J. Bot. 39:1765-1772.

PACLT, J. 1953. Kernbildung der Buche (Fagus silvatica L.) Phytopathol. Z. 20, 255-259.

ZYCHA, H. 1948. Uber die Kernbildung und verwandte Vorgänge im Holz der Rotbucke. Forstwiss. Centralblatt 67:80-109. 